\title{
Activity of Indatuximab Ravtansine against Triple-Negative Breast Cancer in Preclinical Tumor Models
}

\author{
Kurt Schönfeld ${ }^{\prime}$ P Peter Herbener ${ }^{\prime}$ Chantal Zuber ${ }^{\prime} \cdot$ Thomas Häder $^{\prime} \cdot$ Katrin Bernöster ${ }^{2} \cdot$ Christoph Uherek $^{2} \cdot$ jörg Schüttrumpf ${ }^{\prime}$
}

Received: 15 November 2017 / Accepted: 3 April 2018 / Published online: 17 April 2018

(C) The Author(s) 2018

\begin{abstract}
Purpose Triple-negative breast cancer (TNBC) is related with a poor prognosis as patients do hardly benefit from approved therapies. CD138 (Syndecan-1) is upregulated on human breast cancers. Indatuximab ravtansine (BT062) is an antibody-drug-conjugate that specifically targets CD138expressing cells and has previously shown clinical activity in multiple myeloma. Here we show indatuximab ravtansine as a potential mono- and combination therapy for TNBC.
\end{abstract}

Methods The effects of indatuximab ravtansine were assessed in vitro in SK-BR-3 and T47D breast cancer cell lines. The in vivo effects of indatuximab ravtansine alone and in combination with docetaxel or paclitaxel were assessed in MAXF401, MAXF1384 and MAXF1322 xenograft TNBC models.

Results CD138 ${ }^{+}$SK-BR-3 and T47D cells were highly sensitive to indatuximab ravtansine. The high CD138-expressing MAXF401 xenograft model demonstrated strong inhibition of tumor growth with $4 \mathrm{mg} / \mathrm{kg}$ indatuximab ravtansine. High doses of indatuximab ravtansine $(8 \mathrm{mg} / \mathrm{kg})$, docetaxel and the combination of both led to complete remission. In the low CD138-expressing MAXF1384 xenograft model, only combination of indatuximab ravtansine and docetaxel demonstrated a significant efficacy. In the MAXF1322 xenograft model, indatuximab ravtansine alone and in combination with paclitaxel elicited complete remission.

Conclusions These data demonstrate potential use of indatuximab ravtansine in combination with docetaxel or paclitaxel for CD138-positive TNBC.

Jörg Schüttrumpf

joerg.schuettrumpf@biotest.com

Corporate Research \& Development, Biotest AG, Landsteinerstraße 5 63303 Dreieich, Germany

2 Corporate Project \& Portfolio Management, Biotest AG, Landsteinerstraße 563303 Dreieich, Germany
KEY WORDS CDI38 - Indatuximab ravtansine .

Remission · Triple-negative breast cancer · Tumor regression

$\begin{array}{ll}\text { ABBREVIATIONS } \\ \text { EEA-I } & \text { Endosomal antigen-1 } \\ \text { ER } & \text { Estrogen receptor } \\ \text { FACS } & \text { Fluorescence-activated cell sorting } \\ \text { FITC } & \text { Fluorescein isothiocyanate } \\ \text { H\&E } & \text { Hematoxylin and eosin } \\ \text { HBSS } & \text { Hank's balanced salt solution } \\ \text { HER2 } & \text { Human epidermal growth factor receptor } 2 \\ \text { HSPGS } & \text { Heparan sulfate proteoglycans } \\ \text { IC } 50 & \text { Inhibitory concentration } \\ \text { IHC } & \text { Immunohistochemical } \\ \text { IV } & \text { Intravenously } \\ \text { LAMP } & \text { Lysosomal-associated membrane protein } \\ \text { PARP } & \text { Poly ADP-ribose polymerase } \\ \text { PBS } & \text { Phosphate buffered saline } \\ \text { PFA } & \text { Paraformaldehyde } \\ \text { PR } & \text { Progesterone receptor } \\ \text { SC } & \text { Subcutaneously } \\ \text { SEM } & \text { Standard error of the mean } \\ \text { TNBC } & \text { Triple-negative breast cancer }\end{array}$

\section{INTRODUCTION}

Breast cancer represents the most common non-dermatological malignant neoplasm in women and, after lung cancer, it is the second leading cause of cancer-related death among women. In 2016, approximately 40,000 women in the United States died from breast cancer [1], and 92,300 were predicted to die from the disease in Europe [2]. Triple-negative breast cancer (TNBC), in which the estrogen receptor (ER), progesterone receptor $(\mathrm{PR})$, and human epidermal growth factor receptor 2 (HER2) are not expressed [3, 4], accounts for approximately 
170,000 of the 1 million breast cancer cases which are diagnosed worldwide annually [4].

The lack of target receptors (ER, PR, and HER2) means that patients with TNBC do not benefit from hormonal or anti-HER2-based therapy [4]. Moreover, although chemotherapy represents the mainstay of systemic treatment, patients with advanced disease typically respond poorly and rapidly progress [3]. The lack of targeted therapies and the poor prognosis of TNBC means that clinical research in the area of TNBC is of great importance [4].

The ability of tumor cells to invade and metastasize relies on sequential adhesion, motility, and proliferation [5]. Heparan sulfate proteoglycans (HSPGs) are a class of molecules that can influence each of these essential steps [5]. CD138 (syndecan-1) is the most characterized member of the syndecan family, which constitute a major class of cell surface HSPGs [5]. CD138 acts as a receptor for the extracellular matrix and is involved in several cellular functions including cell-cell adhesion, cell-matrix interaction, cellular proliferation, and differentiation [6, 7]. CD138 is overexpressed on malignant plasma cells and expressed by epithelial cells in non-hematopoietic tissue, although transient expression in condensing mesenchyme also occurs during embryonal morphogenesis [7, 8]. Expression of CD138 is widely detected in epithelial neoplasms of various origins and, in rare cases, mesenchymal tumors. Certain pathophysiologic conditions such as tumorigenesis, neoplastic progression, and metastasis can alter the expression of CD138 and its family members [7]. Studies in human breast cancer samples have shown CD138 to be upregulated compared to normal breast tissues, including TNBC which exhibit markedly higher CD138 levels compared to luminal subtypes [7]. Furthermore, CD138 has been reported as a marker of poor prognosis in patients with breast cancer [5].

Indatuximab ravtansine (BT062) is an antibody-drug conjugate based on a murine/human chimeric form of B-B4 (CD138-specific antibody), which is covalently conjugated to the maytansinoid drug DM4 via a disulfide bond-based linker [6]. Maytansinoids are structural analogs of the cytotoxic agent maytansine, which has been evaluated in phase I and phase II clinical trials [9-13]. They exhibit anti-mitotic activity by inducing metaphase arrest of dividing cells, causing cell death [14]. Upon internalization of indatuximab ravtansine by target tumor cells, lysosomal processing of the disulfide linker generates a lysine metabolite which is reduced and Smethylated producing the lipophilic and cytotoxic metabolite, S-methyl-DM4 [6, 15]. The mechanism of action of indatuximab ravtansine resembles that of trastuzumab emtansine, an antibody-drug conjugate indicated for HER2positive metastatic breast cancer which uses the HER2targeting properties of trastuzumab to deliver the cytotoxic DM1 within the cell by means of a stable linker [16]. The intracellular drug delivery to target tumor cells can improve the therapeutic index of the cytotoxic drug and minimize exposure of normal tissue [16].

Indatuximab ravtansine has previously been shown in vivo in multiple myeloma mouse xenograft models to significantly inhibit tumor growth and prolong host survival without any toxicity signals [6]. Based on these preclinical results, a phase I clinical trial of indatuximab ravtansine demonstrated the first signs of clinical activity in patients with relapsed or refractory multiple myeloma without any toxicity signals [17]. Furthermore, preliminary data from a phase I/IIa study in relapsed or refractory multiple myeloma indicated that indatuximab ravtansine is well tolerated even in a multipledose schedule and provided further evidence of clinical activity [18].

To further examine the potential role of indatuximab ravtansine in TNBC, the in vitro mechanistic actions in breast cancer cell lines and its anti-tumor effects in xenograft TNBC models were investigated as monotherapy, and in combination with either docetaxel or paclitaxel.

\section{METHODS}

\section{CDI38 Expression in Primary and Metastatic Breast Cancer Tissues}

Immunohistochemical (IHC) staining was performed on TNBC (ER-/PR-/HER2-negative) samples to determine levels of CD138 expression. Paraffin blocks of TNBC samples were purchased from three sources (Pantomics \#BRM481, Tristar \#69571112, Tristar \#69572306) and cut into $5 \mu \mathrm{m}$ sections. A total of 19 primary breast cancer samples and 42 metastatic breast cancer samples were tested. Samples were mounted on positively-charged glass slides with a maximum of three samples from three different tissues per slide. All experiments included normal human colon and tonsil sections (normal tissue controls) (Ardais Corp, Cooperative Human Tissue Network, Cytomyx, Mercy Health Systems) and HSC4 (JCRB Cell Bank, Japan), ACHN, and T47D (American Type Culture Collection) cells (positive controls) as well as the test samples.

\section{I 38 Expression in Patient-Derived Xenograft Samples}

To confirm CD138 expression in breast cancer xenograft samples, eight samples each from the MAXF1384 (Oncotest), MAXF401 (Oncotest), and MAXF1322 (Oncotest) TNBC xenograft models treated with indatuximab ravtansine, phosphate buffered saline (PBS) or docetaxel were paraffin embedded and assessed by IHC and hematoxylin and eosin (H\&E).

Automated IHC staining was performed with the monoclonal mouse anti-CD138 antibody MI15 (Dako) or an isotype 
Table I IHC scoring system and categories

\begin{tabular}{lllll}
\hline Uniformity (proportion of stained cells) & \multicolumn{2}{l}{ Intensity (brightness of stain) } & Intensity category \\
\hline 0 & Negative & 0 & Negative & Negative \\
Focal & $<25 \%$ & $0-1$ & Very weak & Weak \\
Heterogeneous (hetero) & $25-75 \%$ & 1 & Weak & \\
Homogeneous (homo) & $>75 \%$ & $1-2$ & Weak to moderate & \\
& & 2 & Moderate & Moderate \\
& & $2-3$ & Moderate to strong & Strong \\
& 3 & Strong & \\
\hline
\end{tabular}

control antibody (immunoglobulin IgG1), each diluted in Leica antibody diluent (DakoCytomation) to a concentration of $0.25 \mu \mathrm{g} / \mathrm{mL}$. In addition, all tissue samples were evaluated by $\mathrm{H} \& \mathrm{E}$ staining to determine anatomic site, tumor type and tissue integrity.

\section{Immunohistochemistry Assay}

Staining intensity and proportion of cells stained in each sample type were determined by a Board-certified pathologist. Membrane-associated staining was recorded for all samples and any staining patterns noted. Final scores relate to membrane staining; if only cytoplasmic staining was determined, the final score was reported as zero. Samples were categorized according to their intensity and uniformity as shown in Table I. Examples of the three staining levels are shown in Fig. 1. If there were duplicate results from one patient (i.e. one tissue sample), only the higher score was included in analysis.

\section{38 Expression and Sensitivity to Indatuximab Ravtansine in Breast Cancer Cell Lines}

In order to evaluate the binding and activity of indatuximab ravtansine against breast cancer cell lines, the CD138-positive cell lines SK-BR-3 (American Type Culture Collection) and T47D (American Type Culture Collection) were detached from cell culture flasks by Accutase treatment before incubation of $1 \times 10^{5}$ cells with nBT062, the anti-CD138 antibody moiety of the conjugate indatuximab ravtansine.
nBT062 was diluted in $100 \mu \mathrm{L}$ at concentrations of 0.98 $125 \mathrm{ng} / \mathrm{mL}$. Cells were washed twice and bound nBT062 antibody was detected by fluorescein isothiocyanate (FITC) fluorescence after incubation of the cells with 1/50 diluted FITC-conjugated goat anti-human IgG (Immunotech) in PBS using a fluorescence-activated cell sorting (FACS) Calibur flow cytometer (Beckton Dickinson). All determinations were performed in duplicate samples. Relative fluorescence was calculated using the mean intensity of tested samples with the mean fluorescence of negative controls; untreated cells, isotype control treated cells, and cells treated with the secondary antibody only.

In order to determine sensitivity to indatuximab ravtansine, breast cancer cells at a density of 900 cells/well, were seeded into 96 -well plates and incubated at $37^{\circ} \mathrm{C}$ for $24 \mathrm{~h}$. The active immunoconjugate indatuximab ravtansine was added to wells in triplicate at concentrations of $0.01-$ $100 \mathrm{nM}$, depending on the cell type, and incubated. After 5 days, $10 \mu \mathrm{L}$ of WST-1 reagent containing tetrazolium salt (Roche) was added and incubated for $3 \mathrm{~h}$ and cell viability was quantified by measuring absorbance at $450 \mathrm{~nm}$ versus $690 \mathrm{~nm}$ (reference wavelength) in a microplate reader.

\section{Internalization of Indatuximab Ravtansine into Breast Cancer Cell Lines}

SK-BR-3 cells were seeded on NEXITRON coverslips (Schott Technical Glass Solutions $\mathrm{GmbH}$ ) and cultivated for $48 \mathrm{~h}$ in complete culture medium. Cells were subsequently incubated for $30 \mathrm{~min}$ at $30^{\circ} \mathrm{C}$ with $20 \mu \mathrm{g} / \mathrm{mL}$ of fluorescently a

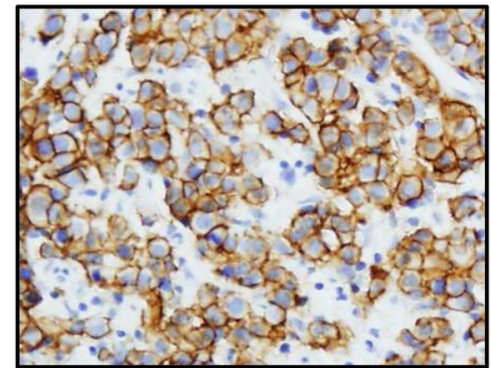

b

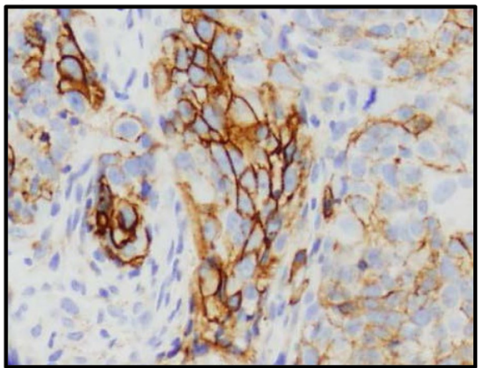

C

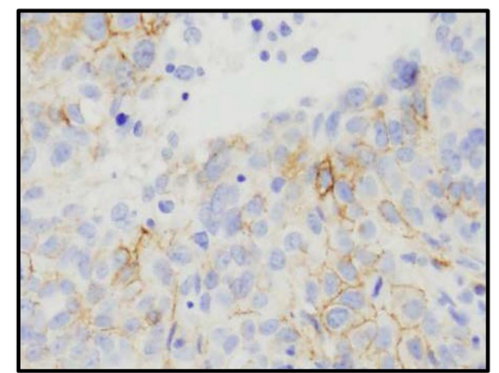

Fig. I Representative CDI38 staining in TNBC samples (20X magnification). (a) Level 3 homogeneous staining, (b) level 2-3 heterogeneous staining, and (c) level I-2 homogeneous staining. 
Table II Study design/dosing in xenograft models MAXFI384 and MAXF40 I

\begin{tabular}{llll}
\hline Compound & Dose & Dosing days & Number of test animals (per xenograft model) \\
\hline Saline & $10 \mathrm{~mL} / \mathrm{kg}$ & $0,7, \mid 4,21,28,35$ & 8 \\
Docetaxel & $10 \mathrm{mg} / \mathrm{kg}$ & $0,7,14$ & 8 \\
Indatuximab ravtansine & $1 \mathrm{mg} / \mathrm{kg}$ & $0,7, \mid 4,21,28,35$ & 8 \\
Indatuximab ravtansine & $2 \mathrm{mg} / \mathrm{kg}$ & $0,7, \mid 4,21,28,35$ & 8 \\
Indatuximab ravtansine & $4 \mathrm{mg} / \mathrm{kg}$ & $0,7, \mid 4,21,28,35$ & 8 \\
Indatuximab ravtansine & $8 \mathrm{mg} / \mathrm{kg}$ & $0,7, \mid 4,21,28,35$ & 8 \\
Indatuximab ravtansine + & $2 \mathrm{mg} / \mathrm{kg}$ & $0,7, \mid 4,21,28,35$ & 8 \\
docetaxel & $10 \mathrm{mg} / \mathrm{kg}$ & $0,7, \mid 14$ & \\
\hline
\end{tabular}

labelled (Dylight 488) nBT062 or the immunoconjugate indatuximab ravtansine. Cells were washed three times with Hank's balanced salt solution (HBSS) and cultivated in complete culture medium for 0-72 h.

Localization of nBT062 and indatuximab ravtansine was assessed by IHC in cells fixed by incubation in $4 \%$ paraformaldehyde (PFA)/PBS at room temperature for $15 \mathrm{~min}$, washed in PBS, permeabilized in $0.02 \%$ Saponin/PBS for $1 \mathrm{~min}$ and subsequently blocked by incubation in $1 \times \mathrm{BMB} /$ PBS for $10 \mathrm{~min}$ (Boehringer Blocking Reagent, Roche). Distribution of fluorescence was assessed by treatment of the cells with fluorescent labelled goat anti-human antibody (Dianova) and incubated at room temperature for $2 \mathrm{~h}$. Cells were washed in PBS and stained in $200 \mu \mathrm{l}$ CellMask ${ }^{\text {TM }}$ Orange Plasma Membrane Stain (Life Technologies)/DRAQ5 solution (1 $\mu \mathrm{g} / \mathrm{mL}$ ) at room temperature for $15 \mathrm{~min}$. Cells were washed in PBS and embedded on microscope slides with DAKO fluorescent mounting medium.

The time course of internalization into SK-BR-3 cells was determined by microscopic analysis. Cells were stained in $200 \mu \mathrm{L}$ CellMask ${ }^{\text {TM }}$ Orange Plasma Membrane Stain (Life Technologies)/DRAQ5 solution for $15 \mathrm{~min}$ at $37^{\circ} \mathrm{C}$, washed in HBSS and fixed by incubation in $4 \%$ PFA/PBS at room temperature for $15 \mathrm{~min}$ and embedded with DAKO fluorescent mounting medium.

Analysis of the subcellular localization of nBT062 and indatuximab ravtansine (both Dylight 488 labelled) was

Table III Tumor control efficacy criteria

\begin{tabular}{ll}
\hline Classification & T/C* \\
\hline Inactive & $\geq 65 \%$ \\
Borderline & $50 \%-<65 \%$ \\
Moderate & $25 \%-<50 \%$ \\
High & $10 \%-<25 \%$ \\
Very high & $5 \%-<10 \%$ \\
Complete remission & $<5 \%$
\end{tabular}

*T/C = median tumor volume in test group/ median tumor volume in control group undertaken by fixing SK-BR-3 cells at $40 \mathrm{~min}, 1,2$, and $4 \mathrm{~h}$ after initial antibody binding and subjected to IHC staining against early endosomal antigen-1 (EEA-1) (rabbit anti-EEA1 antibody, Abcam) or lysosomal-associated membrane protein (LAMP) (rabbit anti-LAMP antibody, Abcam). They were added to permeabilized cells and incubated at room temperature for $1 \mathrm{~h}$. Cells were washed and secondary antibody (goat anti-rabbit Cy3, Dianova), diluted 1:500 was added for $2 \mathrm{~h}$ at room temperature. Cells were washed in PBS and stained for cell nuclei in DRAQ5 solution for $15 \mathrm{~min}$ at room temperature, followed by wash in PBS and embedding on microscope slides with DAKO fluorescent mounting medium.

\section{In Vivo Effect of Indatuximab Ravtansine in Xenograft Models}

All animal experiments were performed at Oncotest $\mathrm{GmbH}$ (Freiburg, Germany). Experiments were approved by the Committee on the Ethics of Animal Experiments of the Regierungspräsidium Freiburg (Freiburg, Germany; permit number: G-13/13) and conducted according to the guidelines of the German Animal Welfare Act (Tierschutzgesetz) and "Principles of Laboratory Animal Care" (NIH publication \#85-23, revised in 1985).

NMRI nude mice were inoculated subcutaneously (SG) with tumor fragments from the low CD138-expressing MAXF1384 or the high CD138-expressing MAXF401 xenografts (Oncotest). Xenografts were passaged three to five times, until there were clear signs of tumor growth.

Animals bearing at least one tumor of $50-250 \mathrm{~mm}^{3}$ (preferably $80-200 \mathrm{~mm}^{3}$ ) were randomized to one study arm (Table II). All drugs were given intravenously (IV) onceweekly over a 5 week cycle. Mortality was assessed daily, and body weight (calculated as relative to day 0 ) and absolute tumor volume twice-weekly. Tumor volume was calculated as $\left(\mathrm{A} \times \mathrm{B}^{2}\right) \times 0.5$, where $\mathrm{A}$ was the largest and $\mathrm{B}$ the perpendicular tumor diameter; tumor volume was calculated relative to day 0 .

Relative tumor volume was used to calculate tumor doubling time and tumor inhibition (median relative tumor 
Table IV Study design/dosing in xenograft model MAXFI 322

\begin{tabular}{|c|c|c|c|}
\hline Compound & Dose & Dosing days & Number of test animals \\
\hline Saline & 10 mL/kg & $0,7, \mid 4,21,28,35$ & 9 \\
\hline Paclitaxel & 10 mg/kg & $1,8,15,22$ & 7 \\
\hline Indatuximab ravtansine & $0.5 \mathrm{mg} / \mathrm{kg}$ & $0,7, \mid 4,21,28,35$ & 7 \\
\hline Indatuximab ravtansine & I mg/kg & $0,7, \mid 4,21,28,35$ & 7 \\
\hline Indatuximab ravtansine & $2 \mathrm{mg} / \mathrm{kg}$ & $0,7, \mid 4,21,28,35$ & 7 \\
\hline Indatuximab ravtansine & $4 \mathrm{mg} / \mathrm{kg}$ & $0,7, \mid 4,21,28,35$ & 7 \\
\hline Indatuximab ravtansine + & I mg/kg & $0,7,|4,2|$ & 5 \\
\hline $\begin{array}{l}\text { paclitaxel } \\
\text { Indatuximab ravtansine + }\end{array}$ & $\begin{array}{l}10 \mathrm{mg} / \mathrm{kg} \\
4 \mathrm{mg} / \mathrm{kg}\end{array}$ & $\begin{array}{l}1,8,15,22 \\
0,7,14,21,28,35\end{array}$ & 7 \\
\hline $\begin{array}{l}\text { paclitaxel } \\
\text { nBT062 }\end{array}$ & $\begin{array}{l}10 \mathrm{mg} / \mathrm{kg} \\
4 \mathrm{mg} / \mathrm{kg}\end{array}$ & $\begin{array}{l}1,8,15,22 \\
0,7,14,21,28,35\end{array}$ & 9 \\
\hline nBT062 + & $4 / 2 / 4 \mathrm{mg} / \mathrm{kg}$ & $0,7 / 14,21 / 28,35$ & 7 \\
\hline $\begin{array}{l}\text { paclitaxel } \\
\text { nBT062 + }\end{array}$ & $\begin{array}{l}10 \mathrm{mg} / \mathrm{kg} \\
4 \mathrm{mg} / \mathrm{kg}\end{array}$ & $\begin{array}{l}1,8,15,22 \\
0,7,14,21\end{array}$ & 4 \\
\hline $\begin{array}{l}\text { DM4 } \\
\text { DM4 }\end{array}$ & $\begin{array}{l}75 \mu \mathrm{g} / \mathrm{kg} \\
75 \mu \mathrm{kg}\end{array}$ & $\begin{array}{l}0,7, \mid 4,21 \\
0,7,14,21\end{array}$ & 4 \\
\hline
\end{tabular}

volume compared with the control group) classified according to predefined criteria (Table III).

\section{Statistical Analysis}

Statistical analysis of tumor inhibition was by the nonparametric Kruskal-Wallis test followed by Dunn's multiple comparison test. Significance for time to tumor inhibition was tested by log-rank Mantel-Cox for pairwise comparisons. Correlation between tumor control and indatuximab ravtansine was analyzed by Spearman correlation analysis with predefined r-values to indicate no, moderate, high, or very high correlation. Significance was determined by conventional $p$-value of $p \leq 0.05$.

In addition, a second study was undertaken in a third xenograft model, MAXF1322, to evaluate the effects of indatuximab ravtansine as monotherapy and in combination with paclitaxel (Table IV). Efficacy was assessed according to tumor volume and maximal tumor inhibition as described in Table III.

\section{RESULTS}

\section{I38 Expression in TNBC Samples}

A high proportion of primary breast cancer samples expressed CD138 (16/19; 84\%) by IHC, however, the majority of these had a weak staining score (Table V). Similarly, the majority of metastatic breast cancer samples also expressed CD138 (33/42; 79\%), however, a higher proportion had moderate or strong IHC staining (Table V). Representative photos of CD138 IHC in TNBC are provided (Fig. 1).

\section{Binding of, and Sensitivity to, Indatuximab Ravtansine against Breast Cancer Cells Lines}

The binding of nBT062 and resulting characterization of CD138 expression indicated variable expression of CD138 between the two cell lines tested; notably, expression was 2fold higher in the SK-BR-3 cell line compared with the T47D line (Table VI). Moreover, SK-BR-3 cells were more sensitive to indatuximab ravtansine as demonstrated by the median inhibitory concentration $\left(\mathrm{IC}_{50}\right)$ values (Table VI).

Sensitivity of the two breast cancer cell lines to indatuximab ravtansine was also studied. Mean $\mathrm{IC}_{50}$ values indicate that the SK-BR-3 cell line $\left(\mathrm{IC}_{50} 2.72 \mathrm{nM}\right)$ was more sensitive to indatuximab ravtansine than T47D cells $\left(\mathrm{IC}_{50} 89.28 \mathrm{nM}\right)$, but sensitivity did not directly correlate with CD138 expression level (i.e. T47D cells were approximately 33 -fold less sensitive to indatuximab ravtansine than SK-BR-3 cells but CD138 expression levels were only around 2-fold lower in the T47D compared to SK-BR-3 cells). On the basis of these results, the indatuximab ravtansine-sensitive breast cancer cell line SKBR-3 was chosen to analyze indatuximab ravtansine internalization properties into cells.

Table V CDI38 expression evaluated by IHC in 6I TNBC tumor microarrays

\begin{tabular}{lll}
\hline Intensity category & $\begin{array}{l}\text { Primary tumor samples } \\
(n=19), \\
\text { Total }(\%)\end{array}$ & $\begin{array}{l}\text { Metastatic tumor samples } \\
(n=42), \\
\text { Total }(\%)\end{array}$ \\
\hline Negative & $3(16 \%)$ & $9(22 \%)$ \\
Weak & $14(74 \%)$ & $14(33 \%)$ \\
Moderate & $2(10 \%)$ & $3(7 \%)$ \\
Strong & $0(0 \%)$ & $16(38 \%)$ \\
\hline
\end{tabular}


Table VI CDI38 expression and sensitivity in SK-BR-3 and T47D cell lines CDI38 expression: Sensitivity to indatuximab Mean relative fluorescence intensity ravtansine:Mean $\mathrm{IC}_{50}[\mathrm{nM}]$ (number of tests) (number of tests)

\begin{tabular}{lll}
\hline SK-BR-3 & $485(4)$ & $2.72(7)$ \\
T47D & $217(4)$ & $89.28(4)$ \\
\hline
\end{tabular}

\section{Internalization of nBT062 and Indatuximab Ravtansine}

Time-dependent analysis of the distribution of indatuximab ravtansine confirmed internalization, with a decrease in extracellular and increase in intracellular localization, so that at $24 \mathrm{~h}$ approximately $50 \%$ of the antibody-conjugate was internalized (Fig. 2).

Distinct cytoplasmic localization of fluorescently labelled nBT062 and indatuximab ravtansine clusters were observed based on EEA1 and LAMP1 staining, with evidence for this internalization via the endolysosomal pathway (Fig. 3).

\section{CDI38 Expression in TNBC Xenograft Models}

IHC analysis of indatuximab ravtansine-treated xenograft mouse models confirmed one with weak CD138 expression
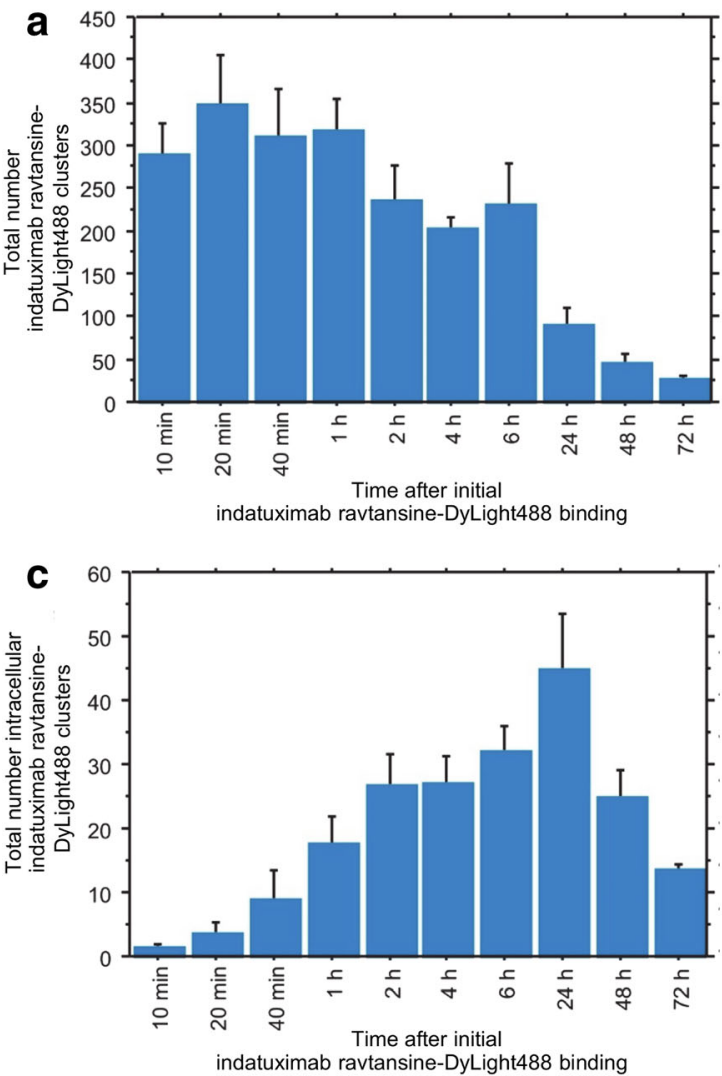

(MAXF1384) and one with strong expression (MAXF401) (Fig. 4).

\section{In Vivo Effect of Indatuximab Ravtansine in Xenograft Models}

In both the low CD138-expressing xenograft (MAXF1384) and high-expressing xenograft (MAXF401) mouse models, biologic activity of indatuximab ravtansine was demonstrated (Fig. 5); although this effect was most notable in the xenograft (MAXF401) with high levels of CD138 expression (Fig. 5a). In this model, relative tumor volumes indicated strong inhibition of growth with indatuximab ravtansine $4 \mathrm{mg} / \mathrm{kg}$ while $8 \mathrm{mg} /$ $\mathrm{kg}$ and the combination of indatuximab ravtansine and docetaxel were significantly superior to control. Docetaxel also demonstrated a significant effect on tumor growth (Fig. 5a). Monotherapy with indatuximab ravtansine $8 \mathrm{mg} / \mathrm{kg}$, docetaxel, and the combination of indatuximab ravtansine and docetaxel led to complete remissions, and according to predefined criteria for response (Table III), indatuximab ravtansine $4 \mathrm{mg} / \mathrm{kg}$ was also highly effective (Table IV).

For the xenograft with low expression of CD138, only the combination of indatuximab ravtansine and docetaxel was significantly superior to control (Fig. 5b), and this regimen
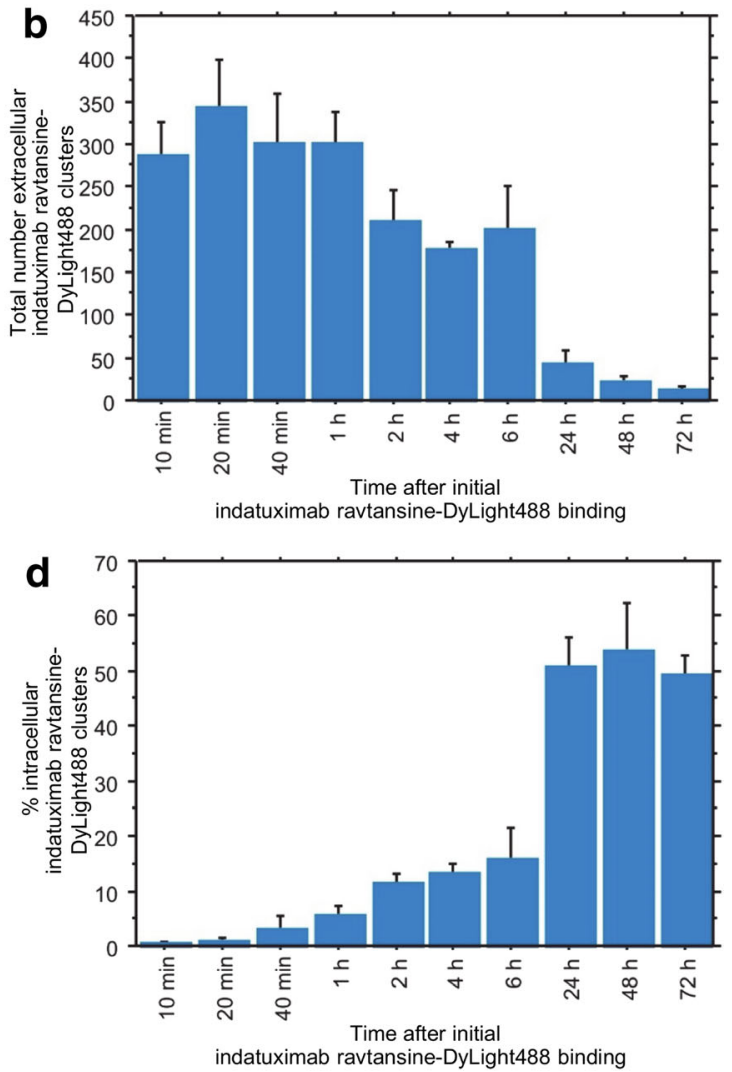

Fig. 2 Time dependent distribution of fluorescently labelled indatuximab ravtansine in SK-BR-3 cells. Quantification of (a) total number of indatuximab ravtansine-DyLight488 clusters, (b) total number of extracellular indatuximab ravtansine-DyLight488 clusters, (c) total number of intracellular indatuximab ravtansine-DyLight488 clusters, and (d) percentage of intracellular indatuximab ravtansine-DyLight488 clusters in relation to total cluster number. Error bars, SEM; $n=3$ for all groups. 


\section{Co-localization of indatuximab ravtansine} and EEA1 after 1 hour

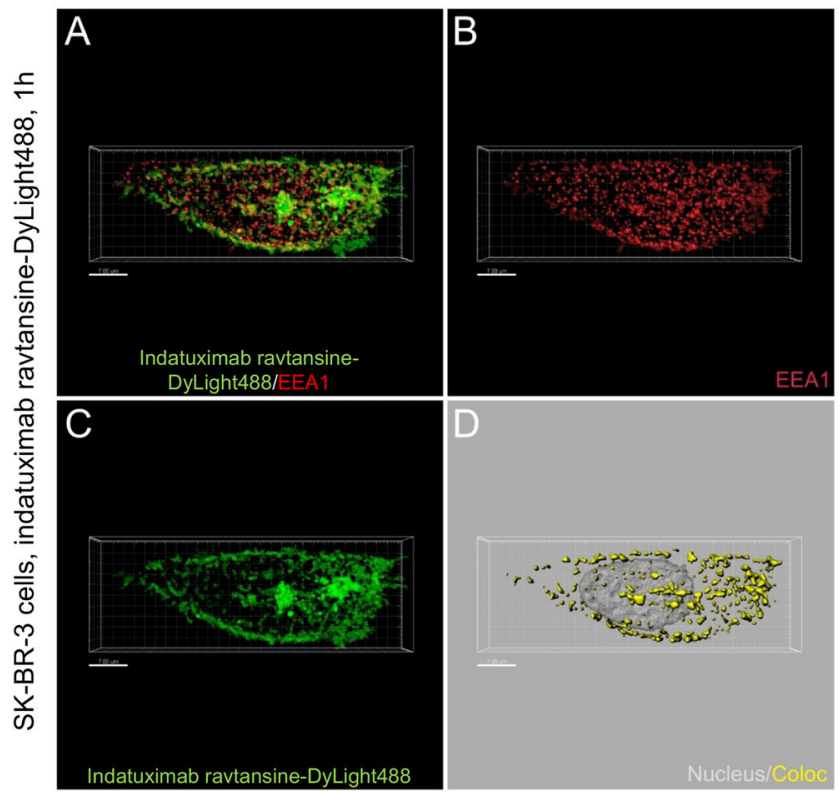

II Co-localization of indatuximab ravtansine and LAMP1 after 4 hours

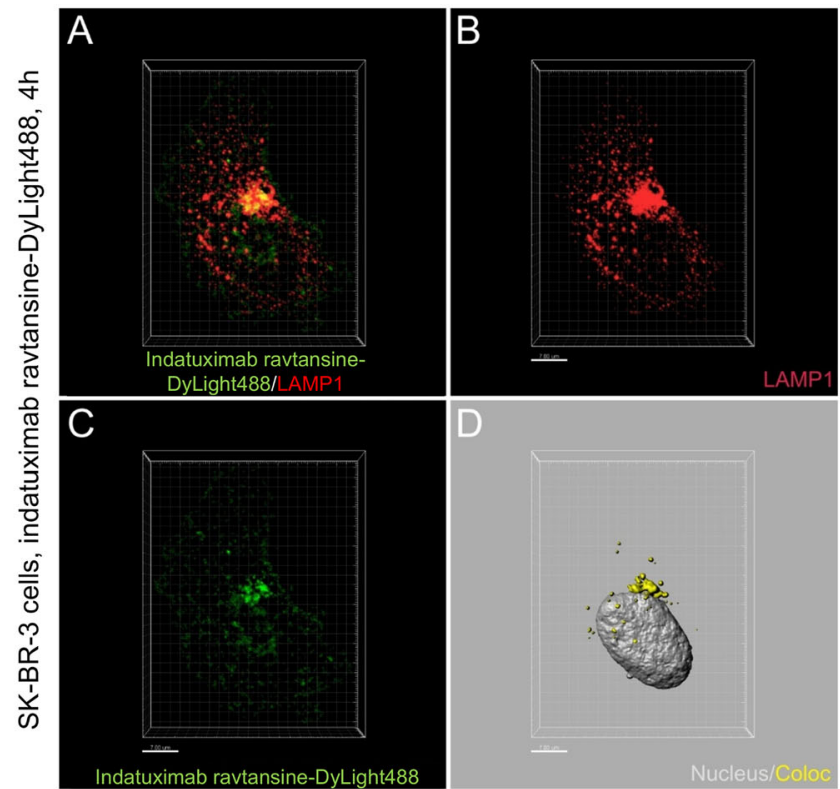

Fig. 3 Internalization of indatuximab ravtansine through the endosomal (I) and lysosomal (II) pathway in SK-BR-3 cells. Grouped panels represent analyses at I and $4 \mathrm{~h}$ after initial antibody binding. (a) Merged DyLight488 (green, indatuximab ravtansine) and Cy3 (red, EEAI [1]; LAMPI [II]) fluorescent z-stack recordings. (b) Cy3 (EEAI [I]; LAMPI [II]) fluorescent z-stack recordings. (c) DyLight488 (indatuximab ravtansine) fluorescent z-stack recordings. (d) 3-dimensional reconstruction of cell nucleus (light grey, nucleus) and portions of DyLight488 fluorescence co-localized to EEAI-postive endosomes [l]; LAMPI-postive lysosomes [II] (yellow, Coloc).

had high and very high anti-tumor activity with minimum T/ $\mathrm{C}$ values of $16.3 \%$ and $8.3 \%$, respectively. However, these data also indicated that at higher doses $(8 \mathrm{mg} / \mathrm{kg})$, indatuximab ravtansine monotherapy had clinical activity even in tumors with a weak CD138 expression.

In addition, using the MAXF1322 model, it was demonstrated that the anti-CD138 antibody nBT062 had no effect on tumor growth. Notably, this model was also resistant to paclitaxel and relatively resistant to DM4 monotherapy. The addition of anti-CD138 antibody to DM4 had no effect on efficacy (Fig. 6), however, the conjugated antibody indatuximab ravtansine $2 \mathrm{mg} / \mathrm{kg}$ and $4 \mathrm{mg} / \mathrm{kg}$ demonstrated anti-tumor activity as monotherapy. The combination of indatuximab ravtansine and paclitaxel was also active. This was confirmed by the tumor control data, where the combination of paclitaxel with indatuximab ravtansine at the highest dose $(4 \mathrm{mg} / \mathrm{kg})$ resulted in complete remission, with an optimal $\mathrm{T} / \mathrm{C}$ value of $0 \%$. The combination of paclitaxel with only $1 \mathrm{mg} / \mathrm{kg}$ indatuximab ravtansine resulted in an optimal $\mathrm{T} / \mathrm{C}$ value of $11.3 \%$. a

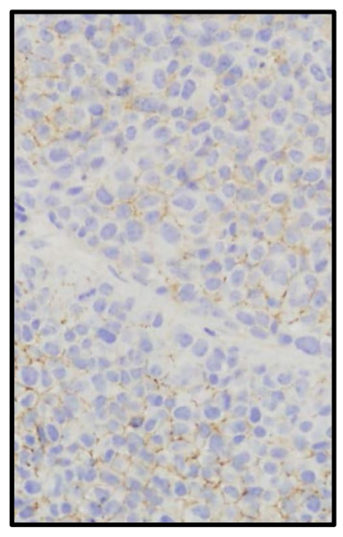

Placebo

Score: $1-2$ focal

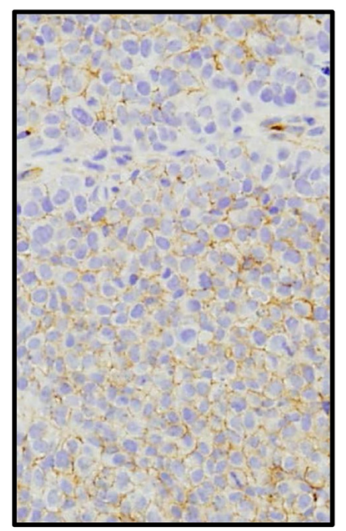

Indatuximab ravtansine $2 \mathrm{mg} / \mathrm{k}$ Score: 1-2 hetero peripheral

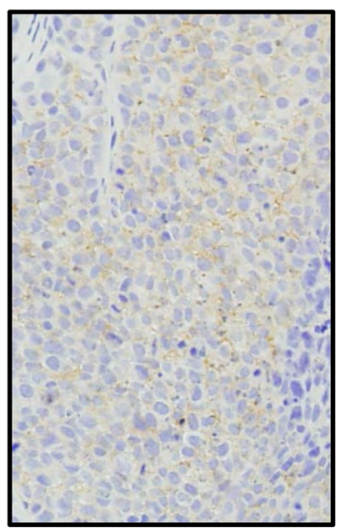

Docetaxel $10 \mathrm{mg} / \mathrm{kg}$ Score: 1-2 focal peripheral b

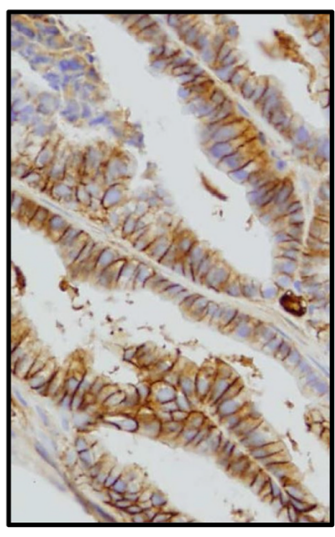

Placebo Score: 2-3 homo peripheral

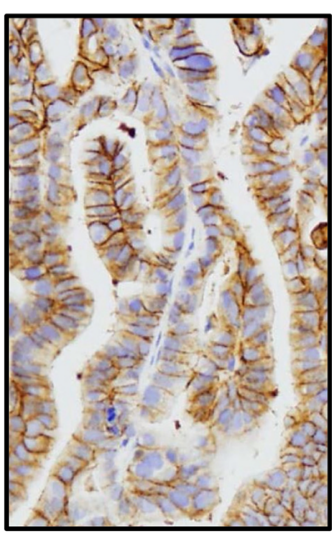

Indatuximab ravtansine $1 \mathrm{mg} / \mathrm{kg}$ Score: 2-3 homo periphery

Fig. 4 Representative staining of CDI 38. IHC CDI38 staining in (a) MAXFI 384 xenograft model with low CDI 38 expression treated with placebo (PBS), $2 \mathrm{mg} / \mathrm{kg}$ indatuximab ravtansine or $10 \mathrm{mg} / \mathrm{kg}$ docetaxel and (b) MAXF40 I xenograft model with high CD I 38 expression treated with placebo (PBS) or I mg/kg indatuximab ravtansine, using monoclonal mouse anti-CD I 38 antibody and H\&E. 
a

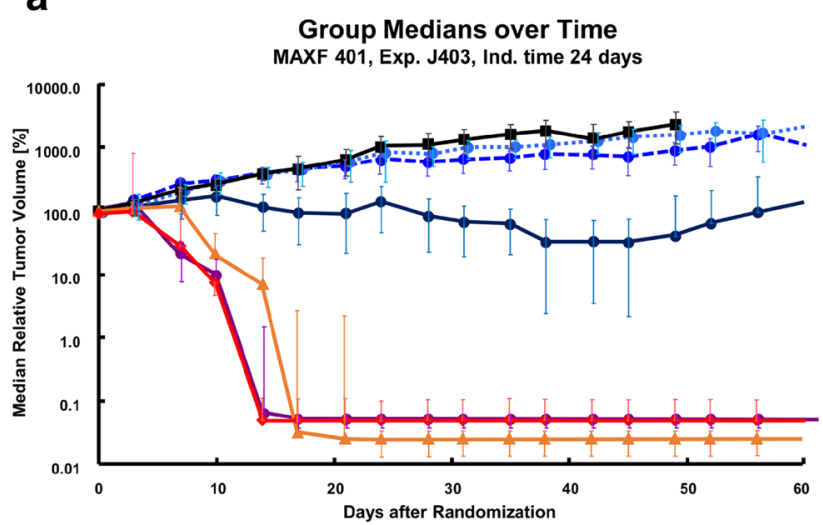

b
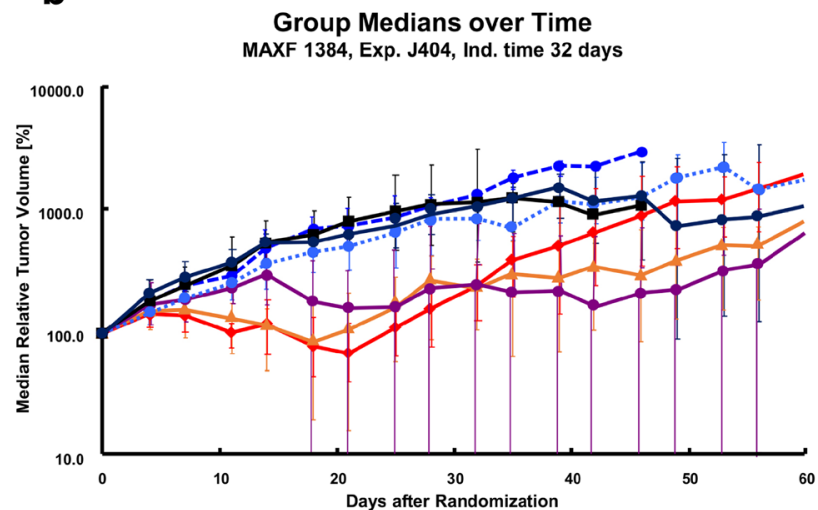

- PBS; 10 mg/kg IV; Days 0, 7, 14, 21, 28, 35

$\smile$ Docetaxel; $10 \mathrm{mg} / \mathrm{kg}$ IV; Days 0, 7, 14

... Indatuximab ravtansine; $1 \mathrm{mg} / \mathrm{kg}$ IV; Days 0, 7, 14, 21, 28, 35

- - Indatuximab ravtansine; $2 \mathrm{mg} / \mathrm{kg}$ IV; Days 0, 7, 14, 21, 28, 35
- Indatuximab ravtansine; $4 \mathrm{mg} / \mathrm{kg}$ IV; Days 0, 7, 14, 21, 28, 35

- - Indatuximab ravtansine; $8 \mathrm{mg} / \mathrm{kg}$ IV; Days $0,7,14,21,28,35$

- Docetaxel/Indatuximab ravtansine; $10 / 2 \mathrm{mg} / \mathrm{kg}$ IV; Days $0,7,14 / 0,7,14,21,28,35$

Fig. 5 Tumor growth curves (relative tumor volume) in MAXF40I and MAXFI384 xenograft models. Median relative tumor volume (\%) was assessed in (a) high CDI38-expressing MAXF40I xenograft model and (b) low CDI38-expressing MAXFI384 xenograft model with different doses of indatuximab ravtansine and docetaxel.

\section{DISCUSSION}

Over the last few years, great strides have been made in breast cancer therapy, however much of this progress has been confined to those patients who overexpress HER2 [3]. TNBC is an aggressive subtype of breast cancer with generally poor prognosis and few available treatment options, which therefore represents a challenge for both patients and clinicians [4, 19].
CD138 is a cell surface integral membrane protein [6], which is variably expressed in a variety of cancers and may play a significant role in mammary carcinogenesis [7]. In a cohort of breast carcinomas with associated distant metastasis, CD138 expression was associated with a higher histologic grade and inversely related to hormonal receptor status [7]. Compared to luminal subtypes, the HER2-positive subtype and TNBC exhibited markedly higher CD138 levels. High
Fig. 6 Tumor growth curves (relative tumor volume) in MAXFI 322 xenograft model. Median relative tumor volume (\%) was assessed in the MAXFI322 xenograft model with different doses of indatuximab ravtansine, paclitaxel (taxol), DM4 and nBT062.

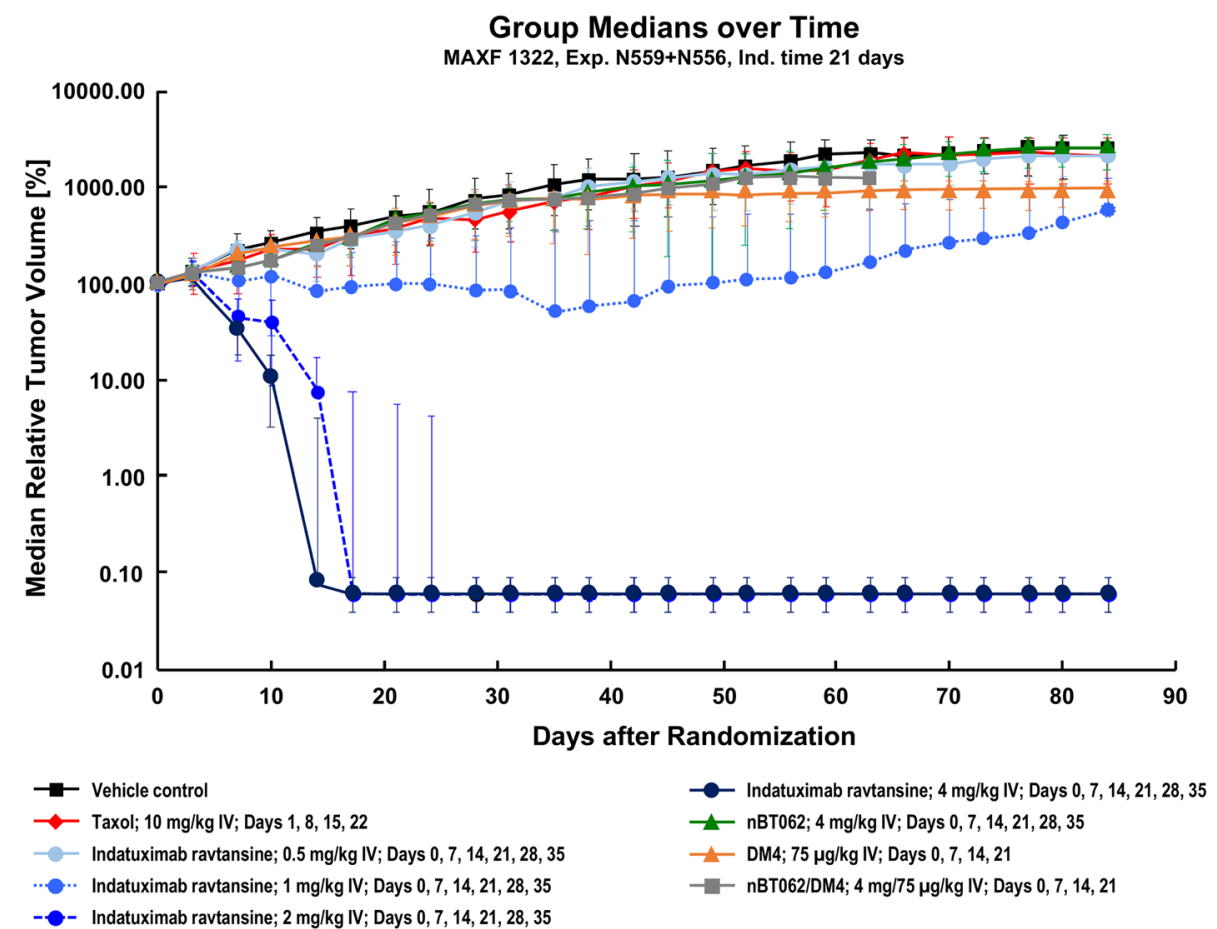


expression of CD138 was associated with a negative impact on both overall and disease-free survival [7]. In this study, a high proportion of primary and metastatic TNBC samples expressed CD138 (84\% and 79\%, respectively) and a higher proportion of metastatic samples had moderate or strong staining in the non-validated IHC assay conducted under GLP standards. The metastatic setting may therefore be the preferred option for subsequent clinical studies of CD138targeted therapy in TNBC.

Indatuximab ravtansine is an antibody-drug conjugate consisting of an anti-CD138 antibody and the cytotoxic maytansinoid agent DM4. Indatuximab ravtansine exerts its anti-tumor effects in a similar manner to trastuzumab emtansine [16]. It specifically binds to CD138-positive cancer cells. Once internalized, a lysine metabolite is generated and DM4 is released, destroying the cancer cell [6, 15]. Studies using multiple myeloma cells have provided a useful insight into the mechanistic activity of indatuximab ravtansine as well as its anti-tumor properties. In vitro studies have shown indatuximab ravtansine to inhibit the proliferation of multiple myeloma cells through induction of $\mathrm{G}_{2}-\mathrm{M}$ cell cycle arrest followed by apoptotic cell death. This was evidenced by dose-dependent cleavage of caspase-8, caspase-9, caspase-3, and poly (ADP-ribose) polymerase (PARP), as well as increased Apo 2.7-positive cells [6]. In this study with breast cancer cell lines, distinct cytoplasmic localization of fluorescently labelled nBT062 and indatuximab ravtansine clusters were also observed.

Previous studies with indatuximab ravtansine in multiple myeloma mouse xenograft models showed significant tumor growth inhibition and prolonged host survival but minimal anti-tumor activity with the unconjugated antibody [6]. Likewise, in this study the unconjugated antibody had no effects on tumor growth in the in vivo MAXF1322 xenograft model. Similarly, the addition of DM4 had no effect on efficacy, however the conjugated antibody indatuximab ravtansine at $2 \mathrm{mg} / \mathrm{kg}$ and $4 \mathrm{mg} / \mathrm{kg}$ demonstrated antitumor activity both as monotherapy and in combination with paclitaxel. The anti-tumor activity of indatuximab ravtansine was also observed in the low CD138-expressing xenograft MAXF1384; and the high-expressing xenograft MAXF401 when used in combination with docetaxel. Only in xenograft model MAXF1384 was indatuximab ravtansine less effective as monotherapy, indicating that higher CD138 expression may be associated with better efficacy.

Rousseau et al. have also shown favorable results of CD138 targeted radioimmunotherapy: Human MDA-MB-468 TNBC bearing mice were treated with the murine antiCD138 antibody B-B4 radiolabeled with ${ }^{131}$ I. In line with the results from our study, they observed a significant reduction of tumor growth in ${ }^{131} \mathrm{I}-\mathrm{B}-\mathrm{B} 4$ treated animals compared to control, despite CD138-expression was low on MDA-MB468 cells, and thus confirming CD138 as suitable target for TNBC therapy [20].
In conclusion, these preclinical data show promising results for the use of the antibody drug-conjugate indatuximab ravtansine for the treatment of patients with TNBCexpressing CD138. In patients with lower expression of CD138, combination with taxanes, such as paclitaxel and docetaxel, may be considered.

\section{ACKNOWLEDGMENTS AND DISCLOSURES}

We thank Ian Morgan, Kalpesh Patel and Katrina Mullin from 4C Consultants International for editing and proofreading of the manuscript. This study was funded by Biotest AG. During data collection, KS, PH, CZ, TH, KB, CU and JS were employees of Biotest AG. CZ, KB, CU and TH are inventors on indatuximab ravtansine related patents. All authors contributed to study design, acquisition of data, analysis and interpretation of data, manuscript drafting and approval. All animal experiments were performed at Oncotest GmbH (Freiburg, Germany). Experiments were approved by the Committee on the Ethics of Animal Experiments of the Regierungspräsidium Freiburg (Freiburg, Germany; permit number: G-13/13) and conducted according to the guidelines of the German Animal Welfare Act (Tierschutzgesetz).

Open Access This article is distributed under the terms of the Creative Commons Attribution 4.0 International License (http://creativecommons.org/licenses/by/4.0/), which permits unrestricted use, distribution, and reproduction in any medium, provided you give appropriate credit to the original author(s) and the source, provide a link to the Creative Commons license, and indicate if changes were made.

\section{REFERENCES}

1. Siegel RL, Miller KD, Jemal A. Cancer statistics, 2016. CA Cancer J Clin. 2016;66(1):7-30.

2. Malvezzi M, Carioli G, Bertuccio P, Rosso T, Boffetta P, Levi F, et al. European cancer mortality predictions for the year 2016 with focus on leukaemias. Ann Oncol. 2016;27(4):725-31.

3. Crown J, O'Shaughnessy J, Gullo G. Emerging targeted therapies in triple-negative breast cancer. Ann Oncol. 2012;23(Suppl 6): vi56-65.

4. Wahba HA, El-Hadaad HA. Current approaches in treatment of triple-negative breast cancer. Cancer Biol Med. 2015;12(2):106-16.

5. Lendorf ME, Manon-Jensen T, Kronqvist P, Multhaupt HA, Couchman JR. Syndecan-1 and syndecan-4 are independent indicators in breast carcinoma. J Histochem Gytochem. 2011;59(6):615-29.

6. Ikeda H, Hideshima T, Fulciniti M, Lutz RJ, Yasui H, Okawa $\mathrm{Y}$, et al. The monoclonal antibody nBT062 conjugated to cytotoxic Maytansinoids has selective cytotoxicity against CD138-positive multiple myeloma cells in vitro and in vivo. Clin Cancer Res. 2009;15(12):4028-37. 
7. Nguyen TL, Grizzle WE, Zhang K, Hameed O, Siegal GP, Wei S. Syndecan- 1 overexpression is associated with nonluminal subtypes and poor prognosis in advanced breast cancer. Am J Clin Pathol. 2013;140(4):468-74.

8. Sanderson RD, Lalor P, Bernfield M. B lymphocytes express and lose syndecan at specific stages of differentiation. Cell Regul. 1989;1(1):27-35.

9. Issell BF, Crooke ST. Maytansine. Cancer Treat Rev. 1978;5(4): 199-207.

10. Blum RH, Maytansine KT. A phase I study of an ansa macrolide with antitumor activity. Cancer Treatment Reports. 1978;62(3): 435-8.

11. Cabanillas F, Rodriguez V, Hall SW, Burgess MA, Bodey GP, Freireich EJ, et al. Study of maytansine using a 3-day schedule. Cancer Treatment Reports. 1978;62(3):425-8.

12. Chabner BA, Levine AS, Johnson BL, Young RC. Initial clinical trials of maytansine, an antitumor plant alkaloid. Cancer Treatment Reports. 1978;62(3):429-33.

13. Eagan RT, Creagan ET, Ingle JN, Frytak S, Rubin J, Phase II. Evaluation of maytansine in patients with metastatic lung cancer. Cancer Treatment Reports. 1978;62(10):1577-9.

14. Remillard S, Rebhun LI, Howie GA, Kupchan SM. Antimitotic activity of the potent tumor inhibitor maytansine. Science. 1975;189(4207): 1002-5.

15. Erickson HK, Park PU, Widdison WC, Kovtun YV, Garrett LM, Hoffman K, et al. Antibody-maytansinoid conjugates are activated in targeted cancer cells by lysosomal degradation and linker-dependent intracellular processing. Cancer Res. 2006;66(8):4426-33.

16. Verma S, Miles D, Gianni L, Krop IE, Welslau M, Baselga J, Pegram M, Oh DY, Diéras V, Guardino E, Fang L, Lu MW, Olsen S, Blackwell K, EMILIA Study Group.; EMILIA study group. Trastuzumab emtansine for HER2-positive advanced breast cancer. N Engl J Med 2012;367(19):1783-1791.

17. Jagganath S, Chanan-Khan A, Heffner LT, Avigan D, Zimmerman TM, Lonial S, et al. BT062, An Antibody-Drug Conjugate Directed Against CD138, Shows Clinical Activity in Patients with Relapsed or Relapsed/Refractory Multiple Myeloma. Blood (ASH Annual Meeting Abstracts). 2011;118: Abstract 305.

18. Heffner LT, Jagannath S, Zimmerman TM, Lee KP, Rosenblatt J, Lonial S, et al. BT062, an antibody-drug conjugate directed against CD138, given weekly for 3 weeks in each 4 week cycle: Safety and further evidence of clinical activity. Blood. 2012;120:Abstract 4042.

19. Black JL, Harrell JC, Leisner TM, Fellmeth MJ, George SD, Reinhold D, et al. CIB1 depletion impairs cell survival and tumor growth in triple-negative breast cancer. Breast Cancer Res Treat. 2015;152(2):337-46.

20. Rousseau C, Ruellan AL, Bernardeau K, Kraeber-Bodéré F, Gouard S, Loussouarn D, et al. Syndecan-1 antigen, a promising new target for triple-negative breast cancer immuno-PET and radioimmunotherapy. A preclinical study on MDA-MB-468 xenograft tumors. EJNMMI Res. 201 1;1:20. 